\title{
Sport and Cultural Events: Willingness to Pay, Facial Expressions and Skin Response
}

\begin{abstract}
By Seppo Suominen*
The topic of this particular study is to combine facial expressions, skin response and willingness to pay (WTP) using an iMotions Platform. This software solution combines biosensors in human behaviour research. A useful method to estimate WTP is contingent valuation method (CV) (Mitchell and Carson 1989). The method has been widely used in cultural economics (Noonan 2003) and sport economics (Walker and Mondello 2007, Wicker et al. 2016a). CV method is made up of using surveys to elicit a willingness to pay for hypothetical changes in some good or service. Galvanic skin response (GSR), also known as electro dermal activity measures electrical activity conducted through sweat glands in the skin. It is an indication of the intensity of an emotion experienced (iMotions). GSR in an indication of stress (arousal of the sympathetic nervous system) in the body by appearing as continuous variation in the electrical characteristics of skin (De Brito and Mitchell 2019). Only joy and surprise are positively related to WTP, while the other emotions do no reveal anything. In addition, heart rate (GSR) and gender are significantly associated with WTP.
\end{abstract}

Keywords: facial expressions, skin response, willingness to pay, sport events, cultural events

\section{Introduction}

Setting the right price for a product or an event, like sporting event or cultural performance, is rather difficult for a marketer. The starting point in cost-based pricing is product, production costs, the price is set based on cost, and marketers need to convince buyers of product's value. The value-based pricing begins with access to customer need and value perceptions, after that the seller sets target price to match customer perceived value and the costs that can be incurred must be determined. Finally, the product should be designed to deliver desired value at target price (Armstrong and Kotler 2014). In value-based pricing customers set the maximum price, they are willing to pay for that event. Top cultural events are rather expensive, the ticket price for an opera performance varies from $35 €$ to $129 €$ (Don Giovanni, $7^{\text {th }}$ March 2020, Helsinki Opera) depending on the seat at the opera, while a typical basketball game ticket is less expensive being about $15-28 €$ (Seagulls vs. Kouvot, $19^{\text {th }}$ November 2019). We know that the spectators of opera and basketball are not the same (Suominen 2013). General belief is that highincome consumers favour cultural performances whereas high-income consumers do no typically attend sport events.

\footnotetext{
"Senior Lecturer, Haaga-Helia University of Applied Sciences, Finland.
} 
Another topic, which is relevant in this particular study, is facial expressions and skin response. There is a wide literature in psychophysiological responses to music (Weth et al. 2015, Sutcliffe et al. 2017, Lynar et al. 2012). Among others, older adults were worse at detecting anger, sadness, fear, and happiness in music. The WTP is first investigated by paper and pen and then the respondents watch a video that contains different music performances and sport events. To the knowledge of the author, no such study of the relation between willingness to pay and biosensor data. The reason and motivation of the study is to explore the possible connections of artificial intelligence and willingness to pay in the sport context.

The topic "willingness to pay" has been widely investigated and there is a numerous literature, for example, the hits at Elsevier Science Direct is more than 55,000. WTP is related to incomes (Wicker 2011) and alternative or reference products. The maximum price $\left(p_{\max }\right)$ is the perceived preference price of the reference product $\left(p_{\text {ref }}\right)$ plus the differentiation value between the reference product and the product of interest $\left(p_{\text {diff }}\right): p_{\max }=p_{\text {ref }}+p_{\text {diff }}$. Suppose you want to see a basketball game. The entrance ticket of the game is $25 €$. You have the option to see the game through the internet at a price of $20 €$ (reference product). However, seeing the game at the venue gives you aesthetic value which is not possible watching through the internet. If the differentiation value is equal or more than $20 €$, then you are willing to pay $25 €$. The economic value is the maximum price that a "smart spectator", fully informed about the market and seeking the best value, would pay. The economic value a person assigns to a product depends on the circumstances under which it is offered. The reservation price $\left(p_{\text {res }}\right)$ is the highest price that a person will accept and still purchase the product. It is the price at which she is just indifferent between purchasing or not purchasing the product. The WTP is the highest price a person is willing to accept to pay for a product. If $p_{\max } \leq p_{\text {res }}$ and the person purchases the product, the reservation price remains an unobservable variable because WTP is determined by the maximum price. If $p_{\max }>p_{\text {res }}$ and the person purchases, willingness to pay is determined by the reservation price. The WTP depends on utility of the good and on the perceived economic value. If the consumer assumes that there is no alternative offering, the WTP equals the utility of the good and its reservation price. However, if the consumer perceives an alternative offering with economic value below utility, the highest price accepted is the economic value of the good and is the maximum price. The novelty of this particular research is to combine artificial intelligence and willingness to pay, and to the knowledge of author, this relation is new in research.

A useful method to estimate WTP is CV (Mitchell and Carson 1989). The method has been widely used in cultural economics (Noonan 2003) and sport economics (Walker and Mondello 2007, Wicker et al. 2016a). CV method is made up of using surveys to elicit a willingness to pay for hypothetical changes in some good or service. Respondents are asked to answer questions as to what actions they would take under a hypothetical event. Although the reliability and validity has been challenged, the method results in good predictions if the field of cultural economics (Noonan 2003) and sport economics (Walker and Mondello 2007). 
CV method has been criticized since the hypothetical WTP may be a poor indicator of actual consumer responses or predictive validity. List and Gallet (List and Gallet 2001), however, find out that private goods generated less hypothetical bias than public goods.

$\mathrm{CV}$ has been widely used in the area of environmental cost-benefit analysis and economics (Venkatachalam 2004). The CV method was proposed in 1947 by Ciriacy-Wantrup (1947). He argued that the prevention of soil erosion generates extra market benefits that are public goods in nature. WTP was according to him one possible method to estimate these public benefits to elicit individuals' opinions. Davis (1963), however, was first to use CV empirically in estimating the benefits of goose hunting among goose-hunters through a survey. $\mathrm{CV}$ is suitable in welfare economics, where a monetary value is places on goods not actually exchanged in the market. Public goods, such as health, education and environmental quality can be measured using CV. In the context of sport and cultural performances, taxpayers' WTP for public subsidies has been measured using CV (Walton et al. 2008, Bille Hansen 1997). The respondent's age, gender and incomes have typically an impact on WTP. The literature on WTP in different sports contexts is extensive (Walker and Mondello 2007, Wicker 2011, Wicker et al. 2016b).

Galvanic skin response (GSR), also known as electro dermal activity measures electrical activity conducted through sweat glands in the skin. It is an indication of the intensity of an emotion experienced (iMotions). GSR in an indication of stress (arousal of the sympathetic nervous system) in the body by appearing as continuous variation in the electrical characteristics of skin (De Brito and Mitchell 2019). Increased skin conductance is associated with higher mental load and/or stress (Epps 2018). The measurement of emotional expression may include different physiological or neural parameters, such as galvanic skin response, heart rate, blood pressure, stomach contractions or dilation of blood vessels (Mainwaring 2011). In the sport context, GSR is common, however mainly in coaching and sport science. High impact sport exercising is related to heart rate level and heart rate variability (Tulppo et al. 1998). GSR in relation to music has been studied somewhat (Berger and Turow 2011).

Facial expression analysis uses webcam to synchronize expressed facial emotions with stimuli directly using a software. An important standard for measuring emotional facial expressions is the Facial Action Coding System (FACS) by Ekman and Friesen (1976). Automated facial expression analysis uses several observable action units that account for facial expressions and in turn for the expression of emotions. The iMotions platform and software classifies emotions into seven categorical emotions: joy, anger, surprise, fear, contempt, sadness and disgust.

A recent review article by Teal et al. (2019) shows that emotions have an important component in pertaining sport sponsorship. Emotions have an impact on intentions and purchasing behaviour. Facial expressions are generated by contractions of facial muscles, which results in facial features such as eyelids and eyebrows, nose, lips and skin texture (Fasel and Luettin 2003). The muscular activities changes are brief, usually less than $5 \mathrm{~s}$ but more than $250 \mathrm{~ms}$. Facial 
expression intensities can be measured by determining the geometric deformation of facial features or the density of wrinkles appearing in certain face regions. The iMotions platform algorithm, Affective AFFDEX uses head orientation (yaw, pitch, roll), interocular distance and 34 facial landmarks and based on these the algorithm classifies seven categorical emotions mentioned above and besides these also valence, engagement and attention. 14 facial expression metrics are calculated.

Soccer teams with displaying both anger and happiness were positively correlated with team performance in the World Cup. Teams with more anger, emotion associated with competitiveness, concede less goals and teams with more happiness, emotion associated with confidence, score more goals (Hopfensitz and Mantilla 2019). However, the results should not be interpreted as teams whose players are angrier or happier perform better since the reverse might be more plausible: performing better leads to angrier or happier faces.

\section{Methodology}

Consider a simple case in which the consumer's purchases are limited to two commodities. Her ordinal utility function is $U=f\left(q_{1}, q_{2}\right)$. A rational consumer wishes to purchase a combination of $\mathrm{q}_{1}$ and $\mathrm{q}_{2}$ from which she derives the highest level of satisfaction. Her income $\mathrm{y}^{0}$ is limited and the budget constraint is $y^{0}=$ $p_{1} q_{1}+p_{2} q_{2}$. The consumer desires to maximize utility subject to budget constraint. The first order condition for a maximum is expressed by the equality of rate of commodity substitution and the price ratio: $\frac{f_{1}}{f_{2}}=\frac{p_{1}}{p_{2}}$. Marginal utility divided by price must be same for all commodities.

Due to data collection method we assume that willingness to pay is related to emotional expression measured by galvanic skin response and facial expression. The data collection uses both iMotion platform and algorithms and we assume that emotional expression measures marginal utility. Before measuring emotional expression, the respondents are asked to fill a questionnaire that includes few questions concerning willingness to pay.

Students of Haaga-Helia University of Applied Sciences first fill in a questionnaire shown in Table 1:

How much would you be at most ready to pay for the events mentioned below? 
Table 1. Questionnaire

\begin{tabular}{|c|c|c|c|c|c|c|}
\hline & $\begin{array}{c}\text { Jazz } \\
\text { music } \\
\text { concert }\end{array}$ & $\begin{array}{l}\text { Aesthetic } \\
\text { Group } \\
\text { gymnastics }\end{array}$ & $\begin{array}{c}\text { Ice } \\
\text { Hockey }\end{array}$ & $\begin{array}{c}\text { Classical } \\
\text { music } \\
\text { concert }\end{array}$ & Athletics & $\begin{array}{c}\text { Rock } \\
\text { music } \\
\text { concert }\end{array}$ \\
\hline $\begin{array}{l}\text { 0, not } \\
\text { interested }\end{array}$ & & & & & & \\
\hline $5 €$ & & & & & & \\
\hline $10 €$ & & & & & & \\
\hline $15 €$ & & & & & & \\
\hline $20 €$ & & & & & & \\
\hline $25 €$ & & & & & & \\
\hline $30 €$ & & & & & & \\
\hline $35 €$ & & & & & & \\
\hline $40 €$ & & & & & & \\
\hline $45 €$ & & & & & & \\
\hline $50 €$ & & & & & & \\
\hline $\begin{array}{l}\text { More } \\
\text { than } 50 €, \\
\text { how } \\
\text { much? }\end{array}$ & & & & & & \\
\hline
\end{tabular}

After having filled the questionnaire, the students watch a video that contains eight different parts, each lasting about one minute. The first is Pekka Pohjola's "First morning" a classical fusion jazz piece of music. Despite that, the album where First morning is included was chosen as the best album of the year by national broadcasting company Yleisradio, probably the students in sample have not heard it before. However, it was not asked. There was no visual content in the video except the album sleeve. The second video clip contains aesthetic group gymnastics, the performance of Minetit, which was the Finnish champion in 2019. The performances in aesthetic group gymnastics are very beautiful but difficult. Most Finns do not know the sports. Based on the author's opinion the audience in aesthetic group gymnastics competitions is made up of solely persons who are relatives of the gymnasts or who are exercise gymnastics themselves. The third video clip contains some moments of the crucial ice hockey game where two Finnish teams, HPK (located in Hämeenlinna) and Tappara (Tampere) were competing on purpose to be the champion of the season 2018-2019. Usually Tappara is considered stronger since it has more financial resources and a better recent record in ice hockey, however, HPK won the game. The fourth video clip is classical music, Karelia by Sibelius. The only visual content is merely a birch forest view with no dynamics. The music was composed in 1893 and well known throughout the whole Finland. The fifth clip contains a pole vault attempt by a female Finn, Minna Nikkanen. She actually passed the bar at the height of $456 \mathrm{~cm}$, which was its time in 2015 the Finnish record. The sixth clip contains punk rock or alternative rock music "Rappiolla" by Hassisen kone. The hit was published in 1980 and it is very popular still today. The video clip contains only black record and no dynamic visual content. The seventh video clip contains a famous music by Lasse Mårtensson: "Myrskyluodon Maija". In the 1970's a television series with the same name was broadcasted. The music in the series was published in 1977. The video clip contains first symphony orchestra version of the music and soprano 
Karita Mattila singing but during the clip, the performance totally changes to Apocalyptica, which is a Finnish symphonic metal band. The last video clip contains the last minute of the 5000 m Olympic competition in 1972 at München, Germany where a Finn, Lasse Viren won the competition. The overall length of the video is about 8 min and $22 \mathrm{sec}$.

Figure 1. The Raw GSR Signal

\section{The raw GSR signal}

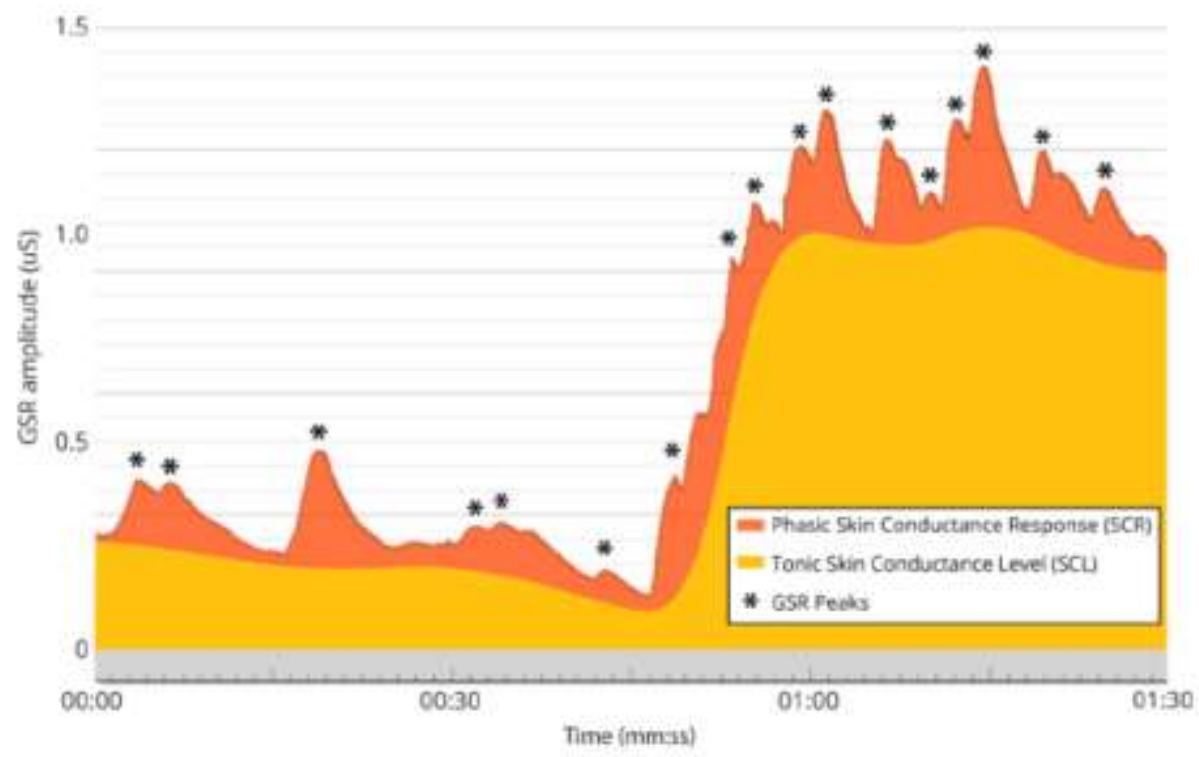

The iMotions platform uses artificial intelligence and classifies facial expression into seven categorical emotions: joy, anger, surprise, fear, contempt, sadness and disgust. The algorithm uses automated facial coding engine called AFFDEX. The facial action coding system (FACS) refers to a set of facial muscle movements that correspond to a displayed emotion (iMotions). Using the system, we are able to determine the displayed emotion of the participant. Affectiva AFFDEX monitors head orientation (yaw, pitch, roll), interocular distance and 34 facial landmarks. The other module of the platform is GSR. The logic behind GSR is simple: place two electrodes on emotionally sensitive body locations, apply a constant low voltage, measure the electrical current between the two electrodes and get the associated skin conductance. The palms of the hands, fingers and foot soles are sensitive recording sites. GSR activity is typically measured in microSiemens $(\mu \mathrm{S})$ (Figure 1).

The original GSR signal can be decomposed into a) duration from stimulus, b) peak amplitude, 3 ) rise time and 4) recovery time (Figure 2). 
Figure 2. GSR Signal Decomposition

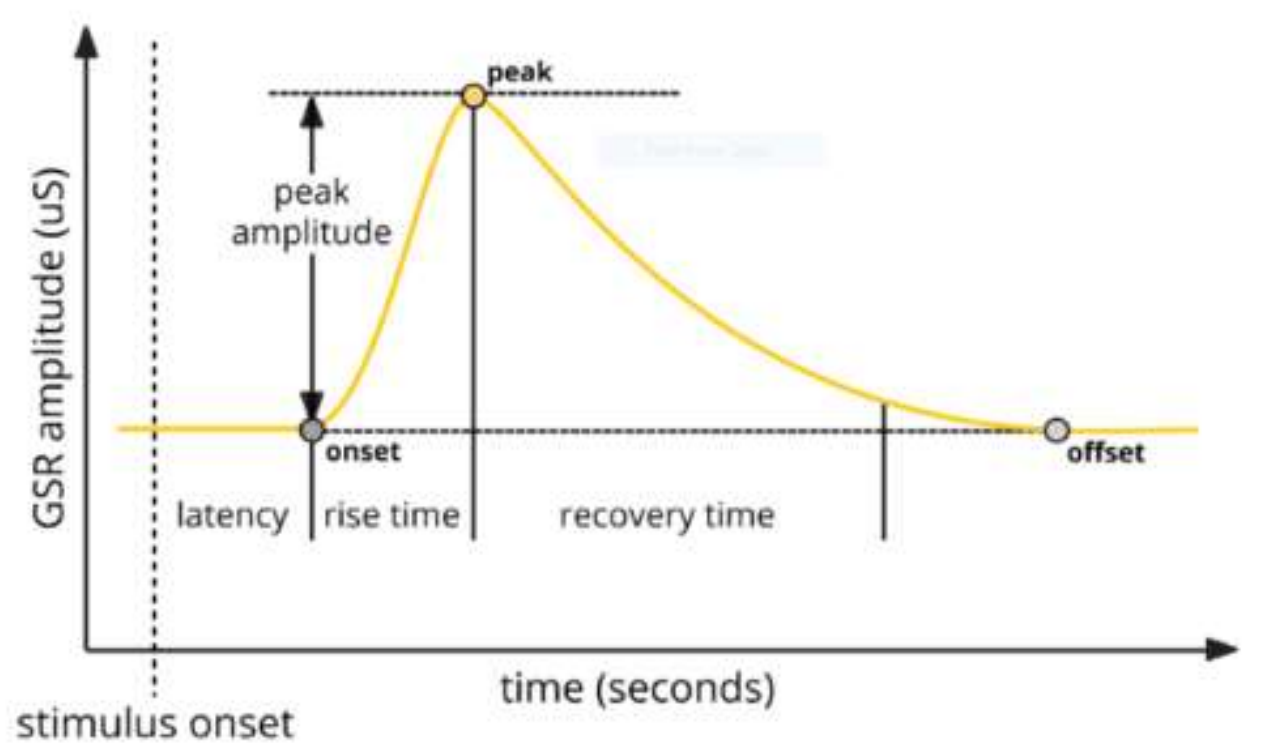

In this particular study, the sites are fingers but only the heartbeat level is used individually in each eight video clip, since in emotional situations bodily processes are triggered automatically: the heart beats faster, the pulse rises and hands become sweaty.

The iMotions Platform is a commercial product. Based on two rather large validation studies (Stöckli et al. 2018) iMotions has potential to measure basic emotions expressed by faces, however, it has problems to distinguish expressions of fear and surprise.

\section{Results}

Due to strict regulations of collecting personal and very sensitive data, the study was able to collect only ten participants' data. They are all studying business at Haaga-Helia University of Applied Sciences. It was not possible to command any person to participate. The first step to analyze the results was to estimate the averages of each emotion and heart rate during each video clip. Some descriptive statistics are presented in Table 2.

Since some emotions are highly positively correlated, each emotion is used individually in relation to each WTP. Willingness to pay is studied in relation to corresponding video clip. The first clip contains jazz music and the corresponding willingness to pay for a jazz music concert is related in the regression analysis. The second willingness to pay question addresses aesthetic group gymnastics and the second video clip contains gymnastics, so each emotion in watching gymnastics are incorporated with this WTP question. The links are shown in Table 3. 
Table 1. Descripive Statistics of Emotions and Heart Rate of Each Individual $n=$ 10

\begin{tabular}{|l|c|c|c|c|c|c|c|c|}
\hline $\mathbf{n = 1 0}$ & \multicolumn{7}{|c|}{ correlation } \\
\hline & mean & contempt & disgust & fear & joy & sadness & surprise & $\begin{array}{c}\text { heart } \\
\text { rate }\end{array}$ \\
\hline anger & 0.839 & 0.491 & 0.714 & -0.076 & -0.074 & 0.813 & -0.042 & 0.072 \\
\hline contempt & 0.303 & & 0.313 & -0.071 & -0.123 & 0.450 & -0.038 & 0.068 \\
\hline disgust & 0.441 & & & -0.042 & -0.348 & 0.466 & 0.111 & -0.067 \\
\hline fear & 2.482 & & & & 0.005 & -0.107 & 0.314 & -0.123 \\
\hline joy & 3.513 & & & & & -0.094 & -0.014 & -0.024 \\
\hline sadness & 1.123 & & & & & & -0.056 & 0.146 \\
\hline surprise & 1.107 & & & & & & & -0.138 \\
\hline heart rate & 83.842 & & & & & & & \\
\hline
\end{tabular}

Table 3. Relations between Willingness to Pay and the Video (or Audio) Clip

\begin{tabular}{|l|c|}
\hline WTP: & video clip \\
\hline jazz music concert & $\leftarrow$ Pekka Pohjola (only audio) \\
34.5 (26.8) & $\leftarrow$ Minetit (visual and audio) \\
\hline $\begin{array}{l}\text { aesthetic group gymnastics } \\
18.5 \text { (14.1) }\end{array}$ & $\leftarrow$ HPK vs. Tappara (vis. \& aud.) \\
\hline $\begin{array}{l}\text { Ice hockey } \\
61 \text { (47.7) }\end{array}$ & $\leftarrow$ Sibelius (only audio) \\
\hline $\begin{array}{l}\text { classical music concert } \\
38.5(42.6)\end{array}$ & $\leftarrow$ Myrskyluodon Maija (vis \& aud) \\
\hline $\begin{array}{l}\text { classical music concert } \\
38.5(42.6)\end{array}$ & $\leftarrow$ Minna Nikkanen (vis \& aud) \\
\hline $\begin{array}{l}\text { Athletics } \\
26(20.5)\end{array}$ & $\leftarrow$ Lasse Viren (vis. \& aud) \\
\hline $\begin{array}{l}\text { Athletics } \\
26(20.5)\end{array}$ & $\leftarrow$ Rappiolla (only audio) \\
\hline Rock music concert & \\
$81(59.1)$ &
\end{tabular}

The regression analysis results on the relation between willingness to pay and different emotions are shown in Table 4. Gender and the age of the respondent are the controlling variables. Women seem to be willing to pay more and heart rate is positively related to willingness to pay. Not all emotions are related to willingness to pay, however, in Table 4 where only the audiovisual clips are used, joy and surprise are positively related to willingness to pay. Tentatively it also seems that age is negatively related to WTP. Age is measured by days, the magnitude is less than $-2 € /$ per year. Despite the fact, the sample is very small; attitude of women to pay more is in line with previous studies (Wicker et al. 2016b). 
Table 4. Regression Analysis -Willingness to Pay in Relation to Gender, Age, Heart Rate and Emotions (Separately), Both Audiovisual and Only Audio Clips

\begin{tabular}{|c|c|c|c|c|c|c|c|c|c|c|c|c|c|c|}
\hline $\mathbf{n}=\mathbf{8 0}$ & \multicolumn{14}{|c|}{ audiovisual (5 clips) and only sound (3) clips } \\
\hline woman & $\begin{array}{c}31.232^{\text {******* }} \\
(9.066)\end{array}$ & $\begin{array}{l}43.261^{* * * *} \\
(11.957)\end{array}$ & $\begin{array}{c}31.337^{* * * *} \\
(8.935) \\
\end{array}$ & $\begin{array}{c}42.724^{* * * *} \\
(11.383)\end{array}$ & $\begin{array}{c}33.418^{* * * * a} \\
(8.807)\end{array}$ & $\begin{array}{l}43.211^{k * k * k} \\
(10.367) \\
\end{array}$ & $\begin{array}{c}33.133^{*{ }^{* * * *}} \\
(8.736) \\
\end{array}$ & $\begin{array}{c}41.127^{* * * k} \\
(10.139)\end{array}$ & $\begin{array}{c}29.303^{* * * *} \\
(8.875)\end{array}$ & $\begin{array}{c}37.155^{* * * *} \\
(10.434)\end{array}$ & $\begin{array}{c}30.015^{* * * *} \\
(9.032)\end{array}$ & $\begin{array}{l}40.694^{* *} \\
(12.633)\end{array}$ & $\begin{array}{c}34.133^{* * * * *} \\
(8.844)\end{array}$ & $\begin{array}{l}41.062^{\text {*** }} \\
(10.142) \\
\end{array}$ \\
\hline age & & $\begin{array}{l}-0.005 \\
(0.003)\end{array}$ & & $\begin{array}{l}-0.005 \\
(0.003)\end{array}$ & & $\begin{array}{l}-0.005 \\
(0.002)\end{array}$ & & $\begin{array}{c}-0.004 \\
(0.002)\end{array}$ & & $\begin{array}{c}-0.004 \\
(0.002)\end{array}$ & & $\begin{array}{c}-0.004 \\
(0.003)\end{array}$ & & $\begin{array}{l}-0.004 \\
(0.003)\end{array}$ \\
\hline $\begin{array}{l}\text { heart } \\
\text { rate }\end{array}$ & $\begin{array}{c}0.497^{*} \\
(0.193)\end{array}$ & $\begin{array}{l}0.571^{* * *} \\
(0.197)\end{array}$ & $\begin{array}{c}0.497^{*} \\
(0.193)\end{array}$ & $\begin{array}{l}0.569^{* * *} \\
(0.197)\end{array}$ & $\begin{array}{l}0.508^{* *} \\
(0.193)\end{array}$ & $\begin{array}{l}0.589^{* * *} \\
(0.196)\end{array}$ & $\begin{array}{c}0.480^{*} \\
(0.193)\end{array}$ & $\begin{array}{l}0.547^{* *} \\
(0.197)\end{array}$ & $\begin{array}{c}0.487^{*} \\
(0.190)\end{array}$ & $\begin{array}{l}0.548^{*} \\
(0.194)\end{array}$ & $\begin{array}{l}0.512^{* *} \\
(0.193)\end{array}$ & $\begin{array}{l}0.562^{* * *} \\
(0.196)\end{array}$ & $\begin{array}{l}0.528^{* *} \\
(0.195)\end{array}$ & $\begin{array}{l}0.576^{* * *} \\
(0.197)\end{array}$ \\
\hline & \multicolumn{2}{|c|}{ anger } & \multicolumn{2}{|c|}{ contempt } & \multicolumn{2}{|c|}{ disgust } & \multicolumn{2}{|c|}{ fear } & \multicolumn{2}{|c|}{ joy } & \multicolumn{2}{|c|}{ sadness } & \multicolumn{2}{|c|}{ surprise } \\
\hline emotion & $\begin{array}{c}-0.668 \\
(1.303)\end{array}$ & $\begin{array}{c}0.585 \\
(1.531)\end{array}$ & $\begin{array}{l}-3.415 \\
(7.867)\end{array}$ & $\begin{array}{c}3.250 \\
(8.909)\end{array}$ & $\begin{array}{c}13.085 \\
(19.450)\end{array}$ & $\begin{array}{c}19.510 \\
(19.553)\end{array}$ & $\begin{array}{l}-0.425 \\
(0.564)\end{array}$ & $\begin{array}{l}-0.364 \\
(0.560)\end{array}$ & $\begin{array}{c}0.540 \\
(0.365)\end{array}$ & $\begin{array}{c}0.477 \\
(0.365)\end{array}$ & $\begin{array}{l}-1.300 \\
(1.310)\end{array}$ & $\begin{array}{l}-0.033 \\
(1.676)\end{array}$ & $\begin{array}{c}0.677 \\
(0.713)\end{array}$ & $\begin{array}{c}0.426 \\
(0.732)\end{array}$ \\
\hline constant & $\begin{array}{l}-19.351 \\
(18.636) \\
\end{array}$ & $\begin{array}{c}27.489 \\
(35.839) \\
\end{array}$ & $\begin{array}{c}-19.168 \\
(18.771) \\
\end{array}$ & $\begin{array}{c}26.100 \\
(34.696) \\
\end{array}$ & $\begin{array}{l}-27.948 \\
(21.488) \\
\end{array}$ & $\begin{array}{c}16.115 \\
(33.099) \\
\end{array}$ & $\begin{array}{c}-18.612 \\
(18.630) \\
\end{array}$ & $\begin{array}{c}22.338 \\
(32.710 \\
\end{array}$ & $\begin{array}{c}-19.887 \\
(18.264) \\
\end{array}$ & $\begin{array}{c}18.169 \\
(32.558) \\
\end{array}$ & $\begin{array}{l}-19.051 \\
(18.463) \\
\end{array}$ & $\begin{array}{c}21.540 \\
(38.382) \\
\end{array}$ & $\begin{array}{l}-25.028 \\
(19.004) \\
\end{array}$ & $\begin{array}{c}15.046 \\
(34.805) \\
\end{array}$ \\
\hline $\mathbf{R}^{2}$ & 0.155 & 0.170 & 0.154 & 0.169 & 0.157 & 0.179 & 0.158 & 0.173 & 0.176 & 0.186 & 0.163 & 0.168 & 0.162 & 0.172 \\
\hline $\mathbf{F}$ & $5.85^{* *}$ & $5.05^{* * *}$ & $5.82^{* *}$ & $5.05^{* *}$ & $5.93^{* *}$ & $5.32^{* * * *}$ & $5.98^{* * * * *}$ & $5.14^{* * * * *}$ & $6.64^{* * 3 *}$ & $5.54^{* * * * *}$ & $6.15^{* * * *}$ & $5.00^{* *}$ & $6.11^{* * 3 *}$ & $5.11^{* *}$ \\
\hline$\chi^{2}$ & $16.63^{* * * *}$ & $19.07^{* * * 3}$ & $16.55^{\text {*a*k }}$ & $19.06^{* 3 * * *}$ & $16.83^{* * * \pi}$ & $19.97^{* * * 1}$ & $16.95^{* * * \pi}$ & $19.37^{* * * \pi}$ & $18.63^{3 * 2 \times 3}$ & $20.72^{* * * \pi}$ & $17.36^{* * * \pi}$ & $18.92^{* * * *}$ & $17.30^{* * * *}$ & $19.28^{* * * *}$ \\
\hline
\end{tabular}

Table 5. Regression Analysis - Willingness to Pay in Relation to Gender, Age, Heart Rate and Emotions (Separately), Only Audiovisual Clips

\begin{tabular}{|c|c|c|c|c|c|c|c|c|c|c|c|c|c|c|}
\hline $\mathbf{n}=\mathbf{5 0}$ & \multicolumn{14}{|c|}{ only if the video clip contains live visual content } \\
\hline woman & $\begin{array}{c}29.309^{* * *} \\
(9.175) \\
\end{array}$ & $\begin{array}{c}43.718^{* * * *} \\
(11.315)\end{array}$ & $\begin{array}{c}28.128^{* * *} \\
(9.165) \\
\end{array}$ & $\begin{array}{l}44.521^{* * * * * *} \\
(12.591)\end{array}$ & $\begin{array}{c}30.369^{* * *} \\
(9.003)\end{array}$ & $\begin{array}{l}41.754^{* * * *} \\
(10.440)\end{array}$ & 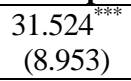 & $\begin{array}{c}41.893^{* * * *} \\
(10.082)\end{array}$ & $\begin{array}{c}24.748^{* * *} \\
(8.254)\end{array}$ & $\begin{array}{c}34.447^{* * * * *} \\
(9.439)\end{array}$ & $\begin{array}{c}29.186^{* *} \\
(9.384) \\
\end{array}$ & $\begin{array}{l}51.297^{* * * *} \\
(12.933)\end{array}$ & $\begin{array}{l}24.274^{* * *} \\
(7.747) \\
\end{array}$ & $\begin{array}{c}30.438^{* * *} \\
(9.370) \\
\end{array}$ \\
\hline age & & $\begin{array}{l}-0.006^{*} \\
(0.003) \\
\end{array}$ & & $\begin{array}{c}-0.007^{(*)} \\
(0.003)\end{array}$ & & $\begin{array}{l}-0.006^{*} \\
(0.003)\end{array}$ & & $\begin{array}{l}-0.005^{*} \\
(0.002)\end{array}$ & & $\begin{array}{c}-0.005 \\
(0.002) \\
\end{array}$ & & $\begin{array}{l}-0.009^{*} \\
(0.003)\end{array}$ & & $\begin{array}{l}-0.003 \\
(0.002)\end{array}$ \\
\hline $\begin{array}{l}\text { heart } \\
\text { rate }\end{array}$ & $\begin{array}{c}0.573^{*} \\
(0.200)\end{array}$ & $\begin{array}{l}0.663^{\text {*** }} \\
(0.199)\end{array}$ & $\begin{array}{l}0.582^{* *} \\
(0.199)\end{array}$ & $\begin{array}{l}0.663^{\text {*** }} \\
(0.199)\end{array}$ & $\begin{array}{l}0.566^{* *} \\
(0.201)\end{array}$ & $\begin{array}{l}0.656^{* * 2} \\
(0.199)\end{array}$ & $\begin{array}{l}0.560^{* *} \\
(0.200)\end{array}$ & $\begin{array}{l}0.643^{\text {** }} \\
(0.198)\end{array}$ & $\begin{array}{l}0.546^{* *} \\
(0.181)\end{array}$ & $\begin{array}{l}0.617^{* * 2} \\
(0.180)\end{array}$ & $\begin{array}{l}0.577^{* *} \\
(0.201)\end{array}$ & $\begin{array}{l}0.681^{* * *} \\
(0.196)\end{array}$ & $\begin{array}{c}0.628^{* * * a} \\
(0.171)\end{array}$ & $\begin{array}{c}0.665^{* * * * 4} \\
(0.174)\end{array}$ \\
\hline & \multicolumn{2}{|c|}{ anger } & \multicolumn{2}{|c|}{ contempt } & \multicolumn{2}{|c|}{ disgust } & \multicolumn{2}{|c|}{ fear } & \multicolumn{2}{|c|}{ joy } & \multicolumn{2}{|c|}{ sadness } & \multicolumn{2}{|c|}{ surprise } \\
\hline emotion & $\begin{array}{l}-0.713 \\
(1.219)\end{array}$ & $\begin{array}{c}0.527 \\
(1.328)\end{array}$ & $\begin{array}{l}-17.487 \\
(17.143)\end{array}$ & $\begin{array}{c}8.596 \\
(21.877)\end{array}$ & $\begin{array}{c}-7.790 \\
(17.550)\end{array}$ & $\begin{array}{c}1.296 \\
(17.560)\end{array}$ & $\begin{array}{l}-0.507 \\
(0.643)\end{array}$ & $\begin{array}{l}-0.370 \\
(0.627)\end{array}$ & $\begin{array}{l}1.047^{*} \\
(0.321)\end{array}$ & $\begin{array}{l}0.980^{k *} \\
(0.313)\end{array}$ & $\begin{array}{l}-0.624 \\
(1.289)\end{array}$ & $\begin{array}{c}1.927 \\
(1.635)\end{array}$ & $\begin{array}{l}62.163^{* \ldots * k} \\
(14.809)\end{array}$ & $\begin{array}{l}56.763^{* * * * *} \\
(15.471)\end{array}$ \\
\hline constant & $\begin{array}{l}-31.391 \\
(9.370)\end{array}$ & $\begin{array}{c}28.718 \\
(34.967)\end{array}$ & $\begin{array}{l}-27.627 \\
(19.735)\end{array}$ & $\begin{array}{c}30.646 \\
(36.948)\end{array}$ & $\begin{array}{l}-28.369 \\
(21.616)\end{array}$ & $\begin{array}{c}23.912 \\
(33.145)\end{array}$ & $\begin{array}{c}-31.043 \\
(19.297)\end{array}$ & $\begin{array}{c}23.576 \\
(32.928)\end{array}$ & $\begin{array}{l}-30.325 \\
(17.420)\end{array}$ & $\begin{array}{c}17.908 \\
(30.020)\end{array}$ & $\begin{array}{l}-31.527 \\
(19.416)\end{array}$ & $\begin{array}{c}48.200 \\
(38.430)\end{array}$ & $\begin{array}{l}-51.860^{* * *} \\
(17.040)\end{array}$ & $\begin{array}{l}-21.079 \\
(31.498)\end{array}$ \\
\hline $\mathbf{R}^{2}$ & 0.222 & 0.272 & 0.233 & 0.272 & 0.219 & 0.269 & 0.226 & 0.275 & 0.363 & 0.399 & 0.220 & 0.291 & 0.433 & 0.437 \\
\hline $\mathbf{F}$ & $5.67^{* * *}$ & $5.58^{* * * * *}$ & $5.99^{\text {*** }}$ & $5.58^{* * * * *}$ & $5.60^{* * *}$ & $5.52^{\text {** }}$ & $5.80^{\text {*** }}$ & $5.65^{* * * * *}$ & $10.32^{* * * *}$ & $9.16^{* * * *}$ & $5.62^{\text {** }}$ & $6.04^{* * * *}$ & $13.50^{* * * *}$ & $10.54^{\text {**** }}$ \\
\hline$\chi^{2}$ & $15.73^{* * * *}$ & $20.14^{\text {**** }}$ & $16.48^{* * * * 2}$ & $20.13^{\text {**:* }}$ & $15.57^{* * * *}$ & $19.97^{* * * *}$ & $16.03^{* * * 3}$ & $20.35^{* * * *}$ & $25.74^{* * * *}$ & $29.78^{* * * *}$ & $15.61^{* * *}$ & $21.48^{* * * *}$ & $31.57^{* * * *}$ & $33.05^{* * *}$ \\
\hline
\end{tabular}


Table 6. Regression Analysis - Willingness to Pay in Relation to Gender, Age, Heart Rate and Emotions (Separately), Only Music Clip without Visual Content, except the Two Last Columns

\begin{tabular}{|c|c|c|c|c|c|c|c|c|c|c|c|c|c|c|c|c|}
\hline $\mathbf{n}=\mathbf{3 0}$ & \multicolumn{14}{|c|}{ only if the video clip does not contain live visual content } & \multirow{2}{*}{ 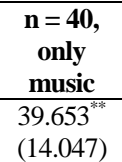 } & \multirow[b]{2}{*}{$\begin{array}{l}44.243^{*} \\
(16.662)\end{array}$} \\
\hline woman & $\begin{array}{c}34.539 \\
(19.539)\end{array}$ & $\begin{array}{c}40.833 \\
(30.910)\end{array}$ & $\begin{array}{c}34.649 \\
(18.500)\end{array}$ & $\begin{array}{c}38.151 \\
(25.031)\end{array}$ & $\begin{array}{l}42.938^{*} \\
(17.080)\end{array}$ & $\begin{array}{l}47.533^{*} \\
(20.435)\end{array}$ & $\begin{array}{c}36.419^{(*)} \\
(8.953)\end{array}$ & $\begin{array}{l}40.159^{(*)} \\
(21.502)\end{array}$ & $\begin{array}{l}41.235^{*} \\
(18.508)\end{array}$ & $\begin{array}{l}47.271^{*} \\
(22.432)\end{array}$ & $\begin{array}{l}32.398^{(*)} \\
(18.086)\end{array}$ & $\begin{array}{c}28.783 \\
(24.750)\end{array}$ & $\begin{array}{c}38.635^{(*)} \\
(7.747)\end{array}$ & $\begin{array}{l}40.410^{(*)} \\
(21.600)\end{array}$ & & \\
\hline age & & $\begin{array}{l}-0.002 \\
(0.009)\end{array}$ & & $\begin{array}{l}-0.001 \\
(0.007)\end{array}$ & & $\begin{array}{l}-0.002 \\
(0.005)\end{array}$ & & $\begin{array}{l}-0.002 \\
(0.006)\end{array}$ & & $\begin{array}{l}-0.003 \\
(0.006)\end{array}$ & & $\begin{array}{c}0.001 \\
(0.007)\end{array}$ & & $\begin{array}{l}-0.001 \\
(0.006)\end{array}$ & & $\begin{array}{l}-0.002 \\
(0.004)\end{array}$ \\
\hline $\begin{array}{l}\text { heart } \\
\text { rate }\end{array}$ & $\begin{array}{c}0.413 \\
(0.388)\end{array}$ & $\begin{array}{c}0.447 \\
(0.414)\end{array}$ & $\begin{array}{c}0.412 \\
(0.387)\end{array}$ & $\begin{array}{c}0.436 \\
(0.410)\end{array}$ & $\begin{array}{c}0.533 \\
(0.366)\end{array}$ & $\begin{array}{c}0.574 \\
(0.384)\end{array}$ & $\begin{array}{c}0.387 \\
(0.389)\end{array}$ & $\begin{array}{c}0.421 \\
(0.409)\end{array}$ & $\begin{array}{c}0.407 \\
(0.381)\end{array}$ & $\begin{array}{c}0.457 \\
(0.399)\end{array}$ & $\begin{array}{c}0.471 \\
(0.287)\end{array}$ & $\begin{array}{c}0.455 \\
(0.401)\end{array}$ & $\begin{array}{c}0.456 \\
(0.403)\end{array}$ & $\begin{array}{c}0.467 \\
(0.414)\end{array}$ & $\begin{array}{l}0.574^{(*)} \\
(0.299)\end{array}$ & $\begin{array}{l}\left.0.611^{*}\right) \\
(0.310)\end{array}$ \\
\hline emotion & \multicolumn{2}{|c|}{ anger } & \multicolumn{2}{|c|}{ contempt } & \multicolumn{2}{|c|}{ disgust } & \multicolumn{2}{|c|}{ fear } & \multicolumn{2}{|c|}{ joy } & \multicolumn{2}{|c|}{ sadness } & \multicolumn{2}{|c|}{ surprise } & \multicolumn{2}{|c|}{ disgust } \\
\hline & $\begin{array}{l}-0.719 \\
(3.267)\end{array}$ & $\begin{array}{c}0.201 \\
(4.832)\end{array}$ & $\begin{array}{c}-3.279 \\
(10.845)\end{array}$ & $\begin{array}{c}-1.805 \\
(13.046)\end{array}$ & $\begin{array}{c}103.591^{(*)} \\
(52.067)\end{array}$ & $\begin{array}{c}104.313^{(*)} \\
(52.934)\end{array}$ & $\begin{array}{c}-0.434 \\
(1.007)\end{array}$ & $\begin{array}{l}-0.425 \\
(1.025)\end{array}$ & $\begin{array}{l}-0.796 \\
(0.850)\end{array}$ & $\begin{array}{l}-0.862 \\
(0.873)\end{array}$ & $\begin{array}{l}-2.724 \\
(2.921)\end{array}$ & $\begin{array}{l}-3.177 \\
(3.625)\end{array}$ & $\begin{array}{c}0.397 \\
(0.963)\end{array}$ & $\begin{array}{c}0.313 \\
(1.082)\end{array}$ & $\begin{array}{l}97.875^{*} \\
(46.136)\end{array}$ & $\begin{array}{l}97.983^{*} \\
(46.607)\end{array}$ \\
\hline constant & $\begin{array}{c}-3.053 \\
(37.403) \\
\end{array}$ & $\begin{array}{c}17.107 \\
(85.669) \\
\end{array}$ & $\begin{array}{c}-3.279 \\
(10.845) \\
\end{array}$ & $\begin{array}{c}11.056 \\
(73.840) \\
\end{array}$ & $\begin{array}{r}-63.935 \\
(45.699) \\
\end{array}$ & $\begin{array}{l}-41.768 \\
(69.745) \\
\end{array}$ & $\begin{array}{c}-1.470 \\
(37.461) \\
\end{array}$ & $\begin{array}{c}17.088 \\
(68.245) \\
\end{array}$ & $\begin{array}{c}-4.099 \\
(36.411) \\
\end{array}$ & $\begin{array}{r}23.749 \\
(67.579) \\
\end{array}$ & $\begin{array}{c}-4.328 \\
(36.416) \\
\end{array}$ & $\begin{array}{l}-19.287 \\
(77.786) \\
\end{array}$ & $\begin{array}{l}-10.732 \\
(40.070) \\
\end{array}$ & $\begin{array}{c}2.219 \\
(81.113) \\
\end{array}$ & $\begin{array}{l}-66.072 \\
(38.162) \\
\end{array}$ & $\begin{array}{l}-42.908 \\
(58.554) \\
\end{array}$ \\
\hline $\mathbf{R}^{2}$ & 0.04 & 0.01 & 0.05 & 0.01 & 0.173 & 0.146 & 0.05 & 0.02 & 0.174 & 0.182 & 0.07 & 0.04 & 0.05 & 0.01 & 0.189 & 0.172 \\
\hline $\mathbf{F}$ & 1.50 & 1.10 & 1.52 & 1.11 & $3.03^{*}$ & $2.25^{(*)}$ & 1.56 & 1.15 & 1.83 & 1.39 & 1.82 & 1.33 & 1.55 & 1.13 & $4.03^{*}$ & $3.03^{*}$ \\
\hline$\chi^{2}$ & 4.80 & 4.88 & 4.85 & 4.90 & $9.00^{*}$ & $9.21^{(*)}$ & 4.96 & 5.09 & 5.74 & 6.03 & 5.73 & 5.79 & 4.94 & 4.98 & $11.59^{* * *}$ & $11.90^{*}$ \\
\hline
\end{tabular}


Results is Table 5 indicate that only with audiovisual element, the facial recognition and galvanic skin analysis with iMotion Platform seem to reveal plausible observations. Only joy and surprise are positively related to WTP, while the other emotions do no reveal anything. Based on validation of the AFFDEX algorithm, it has relatively poor accuracy in fear and anger (Stöckli et al. 2018), therefore it is possible that we find no evidence on the relation between WTP and fear and anger. Without visual content in Table 6 the results suggest that any emotion is not related to WTP except disgust, which is astonishing. Since we have only music recordings in the last subsample without visual content, the disgust or antipathy in relation to music genre is positively related with WTP. This result must be interpreted with caution since the sample size is very small.

The results suggest that dynamic visual content is important in connecting willingness to pay and facial recognition, a still figure without any dynamic visual content does not give enough signals so that we could significantly relate facial recognition and subjective prior wishes.

\section{Summary and Conclusion}

The purpose of this study was to combine artificial intelligence and willingness to pay. First, the respondents were asked to fill a questionnaire. The questions were all in the field of sport and cultural events. In the second phase, they watched a video with eight different sport or music events or music recordings, the length of these were about one minute each. The overall length of the video clips was a bit longer than eight minutes. The results indicate that a dynamic visual content is important. A static figure, like disc cover is not enough, the artificial intelligence is not able to distinguish emotions and combine these with subjective prior wishes on the willingness to pay. The sample size is very small and the iMotion platform is a commercial product not designed for scientific research, however, some interesting results arose. Willingness to pay is positively related to joy and surprise, which is reasonable.

The study reveals that it is possible to combine artificial intelligence, human behaviour and willingness to pay in the sporting or cultural events context. This result is important since with these machine tools we might see in the future a situation in which the machine dynamically changes the price according to the motions that artificial intelligence is able to reveal. If the person in a purchasing situation shows interest towards a good or service and artificial intelligence is able to recognize this interest, then the machine proposes a higher price. Machines might take a role in the price negotiating process. 


\section{References}

Armstrong G, Kotler P (2014) Marketing: an introduction. 12th Global Edition. Pearson.

Berger J, Turow G (2011) Music, science, and the rhythmic brain: cultural and clinical implications. Routledge.

Bille Hansen T (1997) The willingness-to-pay for the royal theatre is Copenhagen as a public good. Journal of Cultural Economics 21(1): 1-28.

Ciriacy-Wantrup SV (1947) Capital returns from soil conservation practices. Journal of Farm Economics 29(4): 1181-1196.

Davis R (1963) The value of outdoor recreation: an economic study of the marine woods. Harvard University.

De Brito SA, Mitchell IJ (2019) The neurobiological underpinnings of psychopathy. In AR Beech, AJ Carter, RE Mann, P Rotshtein (eds.), The Wiley Blackwell Handbook of Forensic Neuroscience, 191-228. Wiley Blackwell.

Ekman P, Friesen WV (1976) Measuring facial movement. Environmental Psychology and Nonverbal Behavior 1(1): 56-75.

Epps J (2018) Task load and stress. In KL Norman, J Kirakowski (eds.), The Wiley Handbook of Human Computer Interaction, volume 1, 215. Wiley Blackwell.

Fasel B, Luettin J (2003) Automatic facial expression analysis: a survey. Pattern Recognition 36(1): 259-275.

Hopfensitz A, Mantilla C (2019) Emotional expressions by sport teams: an analysis of World Cup soccer player portaits. Journal of Economic Psychology 75(Part B): 102071.

Imotions. Galvanic skin response. Retrieved from: https://imotions.com/biosensor/gsr-gal vanic-skin-response-eda-electrodermal-activity/. [Accessed 19 November 2019]

List JA, Gallet CA (2001) What experimental protocol influence disparities between actual and hypothetical values? Environmental and Resource Economics 3(20): 241254.

Lynar E, Cvejic E, Schubert E, Vollmer-Conna U (2012) The joy of heartfelt music: an examination of emotional and physiological responses. International Journal of Psychophysiology 120(Jul): 118-125.

Mainwaring LM (2011) Short-term and extended emotional correlates of concussion. In FM Webbe (ed.), The Handbook of Sport Neuropsychology, 251-274. Springer.

Mitchell RC, Carson RT (1989) Using surveys to value public goods: the contingent valuation method. Washington, D.C.: Resources for the Future.

Noonan DS (2003) Contingent valuation and cultural resources. Journal of Cultural Economics 27(3/4): 159-176.

Stöckli S, Schulte-Mecklenbeck M, Borer S, Samson AC (2018) Facial expression analysis with AFFDEX and FACET: a validation study. Behavior Research Methods 50(3) 1446-1460.

Suominen S (2013) Essays on the demand for cultural performances. Vaasa: University of Vaasa.

Sutcliffe R, Rendell PG, Henry JD, Bailey PE, Ruffman T (2017) Music to my ears: agerelated decline in musical and facial emotion recognition. Psychology and Aging, 32(8): 698-709.

Teal R, Roberts M, Harrigan P, Clarkson J, Rosenberg M (2019) Leveraging spectator emotion: a review and conceptual framework for marketing health behaviors in elite sports. Sport Management Review 23(2): 183-199. 
Tulppo M, Mäkikallio T, Seppänen T, Laukkanen R, Huikuri H (1998) Vagal modulation of heart rate during exercise: effects of age and physical fitness. American Journal of Physiology 274(2): H424-H429.

Venkatachalam L (2004) The contingent valuation method: a review. Environmental Impact Assessment Review 24(1): 89-124.

Walker M, Mondello M (2007) Moving beyond economic impact: a closer look at the contingent valuation method. International Journal of Sport Finance 2(3): 149-160.

Walton H, Longo A, Dawson P (2008) A contingent valuation of the 2012 London Olympic Games. Journal of Sports Economics 9(3): 304-317.

Weth K, Raab MH, Carbon C (2015) Investigating emotional responses to self-selected sad music via self-report and automated facial analysis. Musicae Scientiae 19(4): $412-432$.

Wicker P (2011) Willingness-to-pay in non-profit sports clubs. International Journal of Sport Finance 6(2): 155-169.

Wicker P, Whitehead JC, Johnson BK, Mason DS (2016a) Willingness-to-pay for sporting success of football Bundesliga teams. Contemporary Economic Policy 34(3): 446462.

Wicker P, Whitehead JC, Johnson BK, Mason DS (2016b) Willingness-to-pay for sporting success of football Bundesliga teams. Contemporary Economic Policy, 34(3): 446-462. 
